\title{
Mental health and being smart in Daniel Keyes' Flowers for Algernon
}

\section{Mehmet Ali Çelikel}

Pamukkale University, Turkey / Contact: macelikel@pau.edu.tr

\begin{abstract}
Daniel Keyes' Flowers for Algernon was first published as a short story in The Magazine of Fantasy \& Science Fiction in 1959. After the story successfully elicited critical acclaim and brought literary awards to its author, Keyes expanded the story into a novel that was first published in 1966. Daniel Keyes recounts the saddening story of Charlie Gordon, a mentally retarded thirty-two-year-old man, who is chosen by scientists for an experiment that would supposedly improve one's mental capacity in a short time span. The experiment gradually proves to be successful as Charlie's mental health improves. Yet, as Charlie turns unexpectedly very intelligent and cultured, reaching the ability to speak several languages including Latin, he finds out that the experiment he has been through brings a temporary state of mental well-being to the subject who would quickly return to one's initial mental state. This purpose of paper is to discuss the concept of healing and well-being and question whether being well is an ideological or medical concept in terms of madness and civilization from the perspective of Foulcault who sees madness in a certain cultural space in society which the position and definition of "healthy" individuals depend on.
\end{abstract}

(C) 2020 The Literacy Trek \& the Authors - Published by The Literacy Trek APA Citation

Çelikel, M. A. (2020). Mental health and being smart in Daniel Keyes' Flowers for Algernon. The Literacy Trek, 6(2), 81-90. https://doi.org/10.47216/literacytrek.672319

Published in 1959 as a short story in The Magazine of Fantasy \& Science Fiction, Daniel Keyes' Flowers for Algernon elicited critical acclaim and brought literary awards to its author. In 1969, Keyes expanded the story into an influential science fiction novel that stood out as one of the pioneer examples of novels set in psychiatric wards. Daniel Keyes recounts the saddening story of Charlie Gordon, a mentally retarded thirty-two-year-old man chosen by the doctors for an experiment that would supposedly improve one's mental capacity in a short time span. The experiment gradually proves to be successful and Charlie's intelligence improves. 
Yet, as Charlie turns unexpectedly very intelligent and cultured, reaching the ability to speak several languages, he finds out that the experiment he has been through brings a temporary state of mental well-being to the subject who would quickly return to one's initial mental state.

The purpose of this study is to discuss the concept of healing and well-being and question whether being well is an ideological or medical concept in terms of madness, society and civilization. Although Charlie is mentally retarded rather than being mentally disordered and diseased, his lack of intelligence causes him to be isolated, abased, misconceived and regarded as mad by the members of the society, because he behaves outside the social norms.

Charlie Gordon works at a bakery where he is mocked and laughed at by the people and goes to a school for mentally retarded adults. He never understands what people around him talk about, never understands why they laugh at him, but happy to have friends. His only purpose is to beat Algernon, the laboratory rat, that succeeds all the tasks better than Charlie. His lack of reaction and alertness render him as less individual in the society, a situation that he is not aware of. Miss Kinnian, Charlie's teacher at the school, recommends him to the doctors at a psychiatric hospital where they plan to carry out an experiment for mentally retarded adults.

Madness is a certain cultural space in society and the position and definition of "healthy" individuals depend on the dominant traditional, legal, moral and cultural norms created by the society. Jean Khalfa argues "whether madness is described as a religious or philosophical phenomenon ... or as an objective medical essence ..., these conceptions are not discoveries but historical constructions of meaning" (Khalfa, 2006, p. xiv). As in Khalfa's argument, Charlie falls outside the historical constructions of meaning and being a socially admitted individual. He never realises the fact that he is only socially admitted by the people as long as he patiently lets them laugh at him.

Charlie's "otherness" and his process of change have to be recorded. Thus, he is asked to write down whatever happens to him. The novel opens with "Progress Report 1" full of spelling mistakes to indicate Charlie's lack of writing skills. He is labelled as the "other" due to his mental retardation and this must be recorded and 
shown to people. His mental situation is publicized in order to justify his exclusion and confinement. The novel opens with his first progress report:

\footnotetext{
"progriz riport 1 martch 3

Dr Strauss says I shoud rite down what I think and remember and very thing that happins to me from now on. I don't know why but he says its importint so they will see if they can use me. I hope they use me because Miss Kinnian says mabye they can make me smart ... Dr. Strauss says to rite a lot everything I think and everything that happins to me but I cant think anymore because I have nothing to rite so I will close today ... yrs truly Charlise Gordon." (Keyes, 1989, p. 1)
}

Charlie is not officially confined within a psychiatric ward, but the bakery he works at is his confinement. For the church, both Catholic and Protestant, according to Michel Foucault, "confinement represents an authoritarian model of the myth of social happiness: an order of policing totally transparent to religious principles" (Foucault, 2006, p. 76). Confinement of the individuals labelled as the "other", then, brings happiness to people who feel happy by seeing that they are not like the "others" who are confined. The institutions attempted "to demonstrate that good order could coincide with virtue, and in that sense 'confinement' hides both a metaphysics of the city and a politics of religion" (Foucault, 2006, p. 76). Charlie, as a mentally retarded adult, is in exclusion, which is yet another form of confinement. In Foucauldian terms again, "the people who were locked up were just lunatics, and that behind this obscure practice what we consider an immanent medical justice was hidden" and "the label 'mental patient' and the medical status [were] given to those who were more obviously ill and better recognised" (Foucault, 2006, p. 116). It was a social assumption and normative understanding to exclude and confine "mental patients". Things are much more complicated, argues Foucault, since the history of madness never serves "as a supportive science in the pathology of mental illness" and at a certain moment, madness made possible "a knowledge of alienation according to a style of possibility that isolated it as mental illness" (Foucault, 2006, p. 116).

We should not overlook madness, as argued by Foucault. In European culture, "madness has always welled up simultaneously at multiple points" and, thus, the meaning is "always fractured" (Foucault, 2006, p. 163). What form of knowledge, then, asks Foucault, is "sufficiently singular, esoteric or regional to be given only at a single point, in a unique formulation" and what learning could be "understood to be 
known only in a single time, in a uniform manner in a single mode of apprehension?" (Foucault, 2006, p. 163) Charlie is always understood from a single point of view in which healthiness is only maintained by confining or excluding the diseased as the "other".

Charlie is continuously asked to keep his diary while they prepare him for the operation. During the preparation, he encounters with more people as his curiosity about the operation grows. In the meantime, he is gradually acquainted with the social life and vocabulary that the society introduces him:

\footnotetext{
"He said Harold that's Prof Nemurs frist name I know Charlie is not what you had in mind as the frist of your new breed of intelek** coudnt get the word *** super-man. But most people of his low ment** are host** and uncoop** they are usually dull and apathet** and hard to reach. Charlie has a good natcher and hes intristed and eeger to pleese.” (Keyes, 1989, pp 7)
}

In Foucauldian analysis once again, "the object is slowly seized in the convergence of its profiles" in most forms of knowledge and there, "divergence might be inscribed in the structures themselves, authorizing only a broken, fragmentary consciousness of madness from the outset" (Foulcault, 2006, p. 163-164). Some concepts of a certain arrogance of knowledge, Foucault argues, may mask the "primary dispersion in a superficial manner" because the modern world puts an effort to speak of "madness in the serene, objective terms of mental illness, blotting out its pathetic values in the hybrid meanings of pathology and philanthropy" (Foulcault, 2006, p. 164). Madness turns into a social definition of a state of being. At this stage, Charlie's socialization is beginning to be overwhelming and the thoughts of becoming a different person are frightening for him as so many people looked worriedly at him and wish him luck:

\footnotetext{
"Im skared. Lots of pepul who werk at the collidge and the pepul at the medical school came to wish me luk." (Keyes, 1989, p. 9)
}

Kevin B. Tobia reads Charlie's case as an example of Phineas Gage effect. Phineas Gage was a railroad worker who, in 1848, "suffered an extremely severe and tragic railroad accident in which an iron rod was driven through his frontal lobe" (Tobia, 2015, p. 396). Compared to Phineas before the accident, he was "notably crueller" after the event. He was no more the same person. The case came to be known as "the Phineas Gage effect" from then on. This, comments Tobia, is a 
"striking qualitative change" which "is the alleged severing of personal identity between pre-accident and post-accident Phineas" (Tobia, 2015, p. 396).

John R. Searle argues about this kind of identity change by referring to Phineas Gage effect, too. In personal identity, "there are a variety of criteria that we do in fact employ in deciding questions of the identity of a person across time and change" (Searle, 2008, p. 139). Searle talks about four different criteria to decide "questions of identity" the first and most important of which is "the identity of the body" (Searle, 2008, p. 139). One remains the same person as the person who bears the same body as before. Yet the present body is "spatio-temporally continuous with the body that existed" under the same name at that time (Searle, 2008, p. 139). After the operation, he is not aware of the difference caused by the process. Yet, he notices that he is beginning to learn how to spell properly:

\begin{abstract}
“The operashun dint hert. Dr. Strauss did it while I was sleeping. I don't know how because I dint see but there was bandiges on my eyes and my head for 3 days so I couldnt make no PROGRESS REPORT till today. The skinny nerse who watched me riting says I spelld PROGRESS rong and she told me how to spell it and REPORT to and MARCH." (Keyes, 1989, p. 10)
\end{abstract}

Should Searle's argument be applied to Charlie's case, we might consider that Charlie does not have any physical change after the operation that would create a difference in his manners. On the other hand, the neurological operation he has been gone through makes him accepted and acknowledged by everyone around him. This, in Tobia's words, is an "opposite conclusion" to what is observed in Phineas Gage. Tobia imagines that "Gage had undergone an equally intense change in the opposite direction, improving rather than deteriorating, with reports after the accident indicating the man was much kinder than Phineas before the accident" in which case, "his friends and family might well have claimed he was still Gage" (Tobia, 2015, p. 397). Charlie's case, then, might be regarded as a kinder change in which everyone begins to claim Charlie as a better person in opposition to what he might be thought of in a worse result. His improved spelling, as in the example below, makes him feel better, kinder and more welcomed:

"Today, I learned, the comma, this is, a, comma (,), a period, with, a tail, Miss Kinian, says its, impotent, because, it makes writing, better, she said, ..." (Keyes, 1989, p. 27) 
Donald Palumbo reads Flower for Algernon as an example of monomyth which is defined as a "single 'consciously controlled' pattern most widely exhibited in the world's folk tales, myths, and religious fables" (Palumbo, 2004, p. 427). The morphology of monomyth is that of a quest in which the hero "is called in to an adventure, crosses the threshold to an unknown world to endure tests and trials, and usually returns with a boon that benefits his fellows" (Palumbo, 2004, p. 427). Charlie's case turns into a quest:

"I'm reading a lot these days and almost everything is staying in my mind. Besides history and geography and arithmetic, Miss Kinnian says I should start learning foreign languages." (Keyes, 1989, p. 34)

Palumbo argues that Keyes "makes creative, extensive, and unusually convoluted use of the monomyth" by conceptualizing the "adventure's unknown world or zone of magnified power as Charlie Gordon's intangible realm of increased intellect or comprehension, rather than as a physical location" (Palumbo, 2004, p. 428). Thus, the monomyth's physical journey becomes a psychic journey full of new discoveries and experiences:

"I dropped by the office earlier this evening to ask Dr. Strauss and Professor Nemur if they thought it would be all right for me to ask Alice Kinnian out to a movie, but before I could knock I heard them arguing with each other. I shouldn't have stayed, but it's hard to break the habit of listening because people have always spoken and acted as if I wasn't there, as if they never cared what I overheard.” (Keyes, 1989, p. 48)

Kevin Tobia reads Charlie's case as "a strong example", because Charlie Gordon "begins as mentally disabled and enters a surgery" after which he "is much more intelligent" (Tobia, 2015, p. 401). However, Flowers for Algernon has a more complex pattern than in Phineas Gage in which the patient is crueller or in Searle's argument in which the patient is much kinder. After a period of increased intelligence, the "post-operative Charlie begins to deteriorate, resulting in a less intelligent individual" (Tobia, 2015, p. 401). Kevin Tobia draws a graphical evaluation of Charlie's case:

While pre-operative Charlie (A) seems identical to post-operative Charlie (B), post-operative Charlie (B) seems non-identical to deteriorated Charlie (C). Yet, pre-operative Charlie (A) and deteriorated Charlie (C) are extremely similar to each other (and both are quite dissimilar to (B) post-operative Charlie). What does differ between the comparisons, A-to-B and B-to-C, is the perceived direction of change; A improves to B, and B deteriorates to C. (Tobia, 2015, p. 401) 
Even before deterioration, Charlie understands that intelligence does not bring him any happiness and it merely provides people with social acceptance while too much of it is not positively perceived and welcomed by the society. The social norms that once defined him as mad now categorises him as unsuitably intellectual:

“... I tried to discuss Chaucer with an American literature specialist, questioned an Orientalist about the Trobriand Islanders, and tried to focus on the problems of automation-caused unemployment with a social psychologist who specialized in public opinion polls on adolescent behaviours. They would always find excuses to slip away, afraid to reveal the narrowness of their knowledge.” (Keyes, 1989, p. 69).

His unhappiness indicates the social standards of knowledge. Even as an intellectual, Prof. Nemur has a certain limit of linguistic performance and his capacity of languages cannot be compared to that of Charlie who is outraged by the fact that the scientists who performed the neurological operation on him do not have the full grasp of knowledge about the new developments in the field:

“... Nemur couldn't discuss those article because he hasn't read them. He can't read those languages.

"Not read Hindu and Japanese? Oh, come on now."

"Charlie, not everyone has your gift for languages."

"But how can he refute Rahajamati's attack on this method, and Tanida's challenge to the validity of this kind of control? He must know about those - "

"No...," said Strauss thoughtfully. "Those papers must be recent. There hasn't been time to get translations made."

"You mean you haven’t read them either?" (Keyes, 1989, p. 105)

Charlie, contrary to the unintelligent person he used to be, becomes an overly sophisticated intellectual who questions the requirements of formatted academia. In this format, he thinks, it is unbelievable and unacceptable not to follow the latest developments in their original language, which is yet another issue that excludes him from the standards of society. While his lack of intelligence excluded him from the majority of the society without noticing it before his operation, his sophistication and huge capacity for languages causes a worse exclusion:

"What languages do you know?" I asked him.

"French, German, Spanish, Italian, and enough Swedish to get along."

"No Russian, Chinese, Portuguese?" 
He reminded me that as a practicing psychiatrist and neurosurgeon he had very little time for languages. And the only ancient languages that he could read were Latin and Greek. Nothing of the old Oriental tongues." (Keyes, 1989, p. 105)

After his discovery of how ignorant the scientists in his surgery are, he realizes his loneliness. This realisation fills him with nostalgia and sadness. His sorrowful discovery constructs a dual identity one of which must be destroyed:

"I can't help feeling that I'm not me. I've usurped his place and locked him out the way they locked me out of the bakery. What I mean to say is that Charlie Gordon exists in the past, and the past is real. You can't put up a new building on a site until you destroy the old one, the old Charlie can't be destroyed." (Keyes, 1989, p. 141)

During his researches about the experiment and surgery applied on his brain, he finds out the painful fact:

“ARTIFICIALLY-INDUCED INTELLIGENCE DETERIORATES AT A RATE OF TIME DIRECTLY PROPORTIONAL TO THE QUANTITY OF THE INCREASE.

As long as I am able to write, I will continue to put down my thoughts and ideas in these progress reports. ... However, my mental deterioration will be quite rapid.” (Keyes, 1989, p. 179)

His monomythical journey ends in a mythical tragedy. Charlie's downfall is dramatically juxtaposed against the mythical heroism of a legendary venture to be a more intelligent person. He is now unhappier than ever before:

"Downhill. Thoughts of suicide to stop it all now while I am still in control and aware of the world around me. But then I think of Charlie waiting at the window. His life is not mine to throw away. I've just borrowed it for a while, and now I'm being asked to return it." (Keyes, 1989, p. 195)

His loss of intelligence and sophistication is reflected in his grammatical and spelling errors in his diary. He not only loses his writing skills but also deteriorates in judging what he has been through. During his deterioration, Algernon, the laboratory rat, dies. The novel's saddening finale where he sends a message to Prof. Nemur indicates that he prefers to be laughed at by his friends:

"P. S. please tel prof Nemur not to be such a grouch when pepul laff at him and he woud have more frends. Its easy to have frends if you let pepul laff at you. Im going to have lots of freands where I go.

P. S. please If you get a chance put some flowrs on Algernons grave in the bak yard." (Keyes, 1989, p. 218) 
Flowers for Algernon is not simply the story of Charlie Gordon's mental treatment. It stands out as a criticism forwarded against the normative values of academia that regard Charlie as a subject to be healed through an unprecedented experiment. Charlie's treatment appears to be a burden for relationships within the social norms. The novel focuses on the idea that Charlie is not treated to be well. $\mathrm{He}$ is used as an experiment subject. His mental disease is not something to be cured, but it is rather something to fit the society. Mental healing, thus, turns to be a condition and status to comply with the social values. When Charlie improves extraordinarily, he transforms into an unfitting person as his level of intelligence and culture is over the admissible limits of the society. That level of intelligence is, once again, regarded unsuitable and causes people to run away from him. This makes Charlie wish to go back to his initial situation.

In a brief conclusion, much like the novels of psychiatric wards written in more or less the same milieu and style, Flowers for Algernon is a novel that presents the characteristics of both a science fictional novel and a social criticism. It stands out as a criticism of middle class social norms that categorise all unfitting personalities as diseases. Mental well-being is an ideological and social concept as presented in the novel. Therefore, Charlie's treatment is a process of healing to be diseased.

\section{Notes on the contributor}

Mehmet A. Celikel is a Professor of English Literature at Pamukkale University, Turkey. His research interests are postcolonial fiction, postmodern studies, poetry, geo-criticism.

\section{References}

Foucault, M., Khalfa, J., \& Murphy, J. (Eds.) (2006). History of madness. New York: Routledge.

Keyes, D. (1989). Flowers for Algernon. Oxford: Heinemann.

Khalfa, J. (2006). Introduction. In M. Foucault, J. Khalfa, \& J. Murphy, History of Madness (pp. p. xiii-xxv). New York: Routledge..

Palumbo, D. (2004). The monomyth in Daniel Keyes's 'Flowers for Algernon': Keyes, Campbell and Plato. Journal of the Fantastic in the Arts, 14(4), 427446. 
Searle, J. R. (2008). Philosophy in a new century: Selected essays. Cambridge: Cambridge University Press.

Tobia, K. (2015). Personal identity and the Phineas Gage effect. Analysis, 75(3), 396405. 